\author{
Jarosław Cabaj \\ https://orcid.org/0000-0002-8697-5516 \\ Uniwersytet Przyrodniczo-Humanistyczny w Siedlcach
}

\title{
Prasa ukraińska na Podlasiu w latach 1917-1919
}

\begin{abstract}
Abstrakt: Artykuł jest poświęcony przedstawieniu charakterystyki prasy ukraińskiej ukazującej się w latach I wojny światowej na terenie Podlasia lub poza nim (Brześć), ale adresowanej i docierającej do miejscowej ludności. Czasopisma te mogły ukazywać się dzięki aprobacie niemieckich władz okupacyjnych. Wydawaniem ich zajmowały się organizacje społeczne, religijne i terenowe komórki administracji ukraińskiej. Pisma odgrywały istotną rolę w organizacji działań na rzecz odrodzenia życia narodowego miejscowej ludności oraz upowszechniania idei budowy niepodległego państwa ukraińskiego.
\end{abstract}

Słowa klucz ow e: I wojna światowa, Podlasie, Biała Podlaska, Brześć, prasa ukraińska.

Abstract: The article presents the characteristics of the Ukrainian press published during World War I in the territory of Podlasie or outside it (Brest) but addressed and reaching the local population. These periodicals could be issued owing to the approval of the German occupation authorities. They were published by social, religious, and local units of Ukrainian administration. The periodicals played a vital role in the organisation of activities to revive the national life of local people and to propagate the idea of reconstructing an independent Ukrainian state.

Keyw or d s: World War I, Podlasie, Biała Podlaska, Brest, Ukrainian press.

Nadbużańskie powiaty południowego Podlasia (bialski, włodawski oraz częściowo konstantynowski i radzyński), pozostające w czasie I wojny światowej pod okupacją niemiecka, stały się terenem zorganizowanej działalności ukraińskiej. W 1917 r. w Białej Podlaskiej znajdowało się centrum poczynań Ukraińców - jeńców z armii rosyjskiej, pozyskanych przez Związek Wyzwolenia Ukrainy (ZWU). W mieście tym powstała wówczas Ukraińska Hromada, 
która podjęła działania mające na celu organizację życia narodowego miejscowej społeczności. Od końca marca 1918 r. w nieodległym Brześciu rozpoczęło się tworzenie administracji ukraińskiej, co miało związek z postanowieniami traktatu brzeskiego z 9 lutego tego roku. Swoja siedzibę znalazł tam i stamtąd rozbudowywał swoje struktury terenowe Krajowy Komisariat Ukraińskiej Republiki Ludowej na Chełmszczyznę, Podlasie i Polesie w Brześciu, przekształcony po przewrocie w Kijowie w kwietniu 1918 r. w Chełmskie Starostwo Gubernialne. Po obaleniu Pawła Skoropadskiego została przywrócona poprzednia nazwa tej jednostki. Zarówno Ukraińska Hromada, jak i wymienione struktury państwowe miały swoje organy prasowe. Były to kolejno: „Ridne Słovo” („Рідне Слово”) w Białej Podlaskiej, „Vistnyk Chołmskogo Gubernijalnogo Starostva” (,Вістник Холмського Губерніяльного Староства” [,Vistnyk ChGS”]) w Brześciu, przekształcony po obaleniu Skoropadskiego w „Vistnyk Krajevogo Komysarijatu Ukrajinskoj Narodnoj Respubliki na Chołmščynu, Pidljašje i Polissje” („Вістник Краевого Комисаріяту Українськой Народрньої Республіки на Холмщину, Підляше й Поліссе" [,Vistnyk KK”]). W Brześciu, za zgodą i przy wsparciu Chełmskiego Starostwa Gubernialnego, wydawano tygodnik „Myr” (Мир), redagowany przez księdza greckokatolickiego Mychajłę Kita, a adresowany przede wszystkim do mieszkańców Chełmszczyzny i Podlasia.

W centrum zainteresowania pozostaja zatem cztery czasopisma ukraińskie wydawane w powiatach nadbużańskich bądź też poza nimi, adresowane do mieszkańców tych terenów. Są to: społeczno-kulturalne „Ridne Słovo”, urzędowe „Vistnyk ChGS” i „Vistnyk KK” oraz społeczno-religijny „Myr”. Celem artykułu jest ogólna charakterystyka tych pism, ukazanie ich znaczenia w organizowaniu życia narodowego miejscowej ludności ukraińskiej oraz wspieraniu działań propaństwowych. Ramy chronologiczne obejmują okres niespełna dwóch lat, począwszy od czerwca 1917 r., gdy w Białej Podlaskiej ukazał się pierwszy numer „Ridnego Słova”. Cezurę końcowa stanowi początek lutego $1919 \mathrm{r}$. W tamtym czasie polskie wojska zajęły Brześćc ${ }^{1}$. Likwidacji uległ ośrodek ukraiński wydający czasopisma.

W artykule nie podejmuję charaterystyki „Visnyka Sojuzu Vyzvołennja Ukrajiny” („Вісник Союзу Визволення України”), ukazującego się w Wiedniu organu prasowego ZWU. Pismo to za pośrednictwem działaczy ZWU, organizatorów Ukraińskiej Hromady w Białej Podlaskiej, docierało zapewne na tereny nadbużańskie okupowane przez Niemców. Na jego łamach wielokrotnie pojawiały się informacje z terenu Chełmszczyzny i Podlasia. Doczekało się ono odrębnego opracowania naukowego ${ }^{2}$.

1 J. Grobicki, Zajęcie Brześcia Litewskiego w lutym 1919 r. i poprzedzajace je wypadki na Podlasiu, „Bellona” 1932, t. XXXIX, s. 416-419.

2 О. Супронюк, Часопис «Вісник Союзу Визволення України» (Відень, 1914-1918) як чинник становлення державності України, „Наукові записки Національного університету «Острозька академія». Серія «Історичні науки»" 2015, Вип. 23, с. 59-64. 
Problematyka prasy ukraińskiej, ukazującej się na terenach nadbużańskich w latach I wojny światowej, nie była dotychczas podejmowana w opracowaniach historycznych. Wzmianki o wymienionych tytułach zostały zamieszczone w zestawieniu przygotowanym przez autorów ukraińskich Igora Pawljuka i Mykołę Martyniuka ${ }^{3}$. W spisie czasopism ukraińskich, opracowanym przez Eugeniusza Misiłę, znalazł się jedynie „Myr”. Działania Ukraińskiej Hromady w Białej Podlaskiej, w tym również wydawanie „Ridnego Słova” ukazali w swoich publikacjach Jevgen Pasternak ${ }^{5}$, Jarosław Cabaj ${ }^{6}$ i Iwan Pater ${ }^{7}$. Różne aspekty aktywności ukraińskiej w powiatach nadbużańskich w latach I wojny światowej przedstawili Juryj Makar ${ }^{8}$, Mychajło Hornyj ${ }^{9}$, Grzegorz Kuprianowicz ${ }^{10}$, a także Rafał Dydycz, ten ostatni w rozprawie doktorskiej przygotowanej na Uniwersytecie Przyrodniczo-Humanistycznym w Siedlcach ${ }^{11}$.

Bazę źródłową opracowania podjętej problematyki stanowią wspomniane wyżej tytuły prasy ukraińskiej. Niemal kompletne jej zbiory są dostępne w bibliotekach lwowskich. Dotarcie do nich umożliwiły mi kwerendy realizowane w ramach tematu badawczego ${ }^{12}$. Cenne informacje dotyczące niektórych aspektów działalności ukraińskiej na Podlasiu zawarł w swoich wspomnieniach Ołeksandr Skoropys-Jołtuchowski ${ }^{13}$, chełmski komisarz krajowy i starosta gubernialny w Brześciu.

\section{Charakterystyka czasopism i uwarunkowania ich wydawania}

Zarówno wydawanie i kolportaż opisywanych czasopism, jak i działalność utrzymujacych je organizacji i ukraińskich struktur państwowych odbywały

${ }^{3}$ І. Павлюк, М. Мартинюк, Хрестолатія украӥнськой преси Волині, Полісся, Хомщини та Підляшшя 1917-1939, 1941-1944 рр., Луцьк 2005, с. 381-405.

${ }^{4}$ E. Misiło, Spis tytułów prasy ukraińskiej w Drugiej Rzeczypospolitej 1918-1939, Warszawa 1983, s. 46.

${ }_{5}^{5}$ Є. Пастернак, Нарис історї Холмщини і Підляшщя (новіші часи), Вінніпег-Торонто 1968.

${ }^{6}$ J. Cabaj, Społeczeństwo guberni chetmskiej pod okupacjq niemieckq $i$ austriackq $w$ latach I wojny światowej, Siedlce 2006.

${ }^{7}$ I. Патер, Союз визволення України. Проблеми держсавності і соборності, Львів 2000, c. $187-225$.

${ }^{8}$ Ю. Макар, Холмщина і Підляшшя в першій половині ХХ століття. Історико-політична проблелтика, Львів 2003.

${ }^{9}$ М. Горний, Украӥнська інтелігенція Холмщини і Підляшщя у XX ст., Львів 2002.

${ }^{10}$ Г. Купріянович, Украӥнський етнос на Холмщини та Підляшші у XIX-XX cm., в: Холмшина та Підляшшя. Історико-етнографічне дослідження, ред. В. Борисенко, Київ 1997, с. 59-76.

${ }^{11}$ R. Dydycz, Od narodzin do likwidacji. Ukraińska działalność polityczna, społeczna, kulturalno-oświatowa $i$ gospodarcza na terenie powiatu bialskiego w latach 1917-1947, mps rozprawy doktorskiej, Siedlce 2019.

12 Temat badawczy nr 271/11/S („Prasa podlaska w XIX-XXI wieku”), sfinansowany z dotacji na naukę, przyznanej przez Ministerstwo Nauki i Szkolnictwa Wyższego.

13 О. Скоропис-Йолтуховський, Мої „злочини”, „Хліборобська Україна” (Відень) 1920-1921, т. $2-4$. 
się za zgodą niemieckich władz okupacyjnych (Ober-Ost) i dzięki wsparciu komendantur terenowych.

Spośród wymienionych pism ukraińskich najwcześniej zaczęło ukazywać się „Ridne Słovo”. Pierwszy jego numer pojawił się 23 VI 1917 r. Pismo w założeniach miało być tygodnikiem. Na ogół zachowywano tę częstotliwość wydawania. Pewnym odstępstwem były podwójne numery, np. 3 i 4 z 14 VII 1917 r. Kolejne wychodziły już bez zakłóceń. Łącznie do końca 1917 r. ukazało 28 numerów pisma, ostatni z nich z datą 29 grudnia. W 1918 r. pismo wydawano regularnie zapewne do listopada. Ostatni egzemplarz, do którego dotarłem, opatrzony numerem 43, licząc zaś od początku ukazywania się pisma - 71, pochodził z 26 października. Na podstawie informacji zamieszczonej w kolejnym zachowanym wydaniu ze stycznia 1919 r. dowiadujemy się, że pismo nie ukazywało się dwa miesiące ${ }^{14}$. Miało to zapewne związek z wycofywaniem się Niemców z terenu Podlasia. Wraz z nimi ewakuowali się też działacze ukraińscy, którzy ze swoim wydawnictwem znaleźli siedzibę w Brześciu. Tam też ukazało się wspomniane wydanie z 1919 r., opatrzone numerem 74. Należy więc przyjąć, że po 26 października prowadzono przez jakiś czas działalność wydawnicza. Jej owocem były dwa numery tygodnika.

Egzemplarz pisma ze stycznia 1919 r., z adnotacja o Brześciu jako miejscu ukazania się, to ostatni z zachowanych. W związku z ewakuacją wojsk niemieckich i zajmowaniem przez Polaków terenów nadbużańskich i miasta, co nastapiło w lutym 1919 r., komisariat ukraiński i redakcja „Ridnego Słova” zakończyły działalność.

„Ridne Słovo” - w dosłownym tłumaczeniu „rodzime/ ojczyste słowo” miało podtytuł „ukraińskie czasopismo ludowe”. Jak wynika z dostępnych źródeł, wydawano je w nakładzie 2 tys. egzemplarzy. Układ i szata graficzna „Ridnego Słova” nie ulegały istotnym zmianom przez cały okres blisko 20 miesięcy ukazywania się pisma. Do czytelników trafiało za pośrednictwem placówek ukraińskich, przede wszystkim szkól, a także struktur terenowych Ukraińskiej Hromady i niemieckich urzędów okupacyjnych ${ }^{15}$. Pismo tworzył komitet redakcyjny w składzie: Mykoła Sołowiejczuk, Stefan Korduba i Wasyli Usenko, wywodzacy się z ZWU. Redakcja mieściła się w Białej Podlaskiej przy ul. Długiej 11, w dwukondygnacyjnym budynku zajmowanym przez Ukraińską Hromadę. W styczniu 1919 r. - jak wskazano wyżej - pismo ukazało się w Brześciu.

W ostatnim numerze, ze stycznia 1919 r., redakcja w nostalgicznym tonie przedstawiła swoje zasługi dla odrodzenia narodowego, podkreśliła, że „Ridne Słovo" było pierwszym ukraińskim pismem wydawanym na Podlasiu. Odwołujacc się do początków pracy, podkreśliła, że gazeta wchodziła na teren, gdzie wcześniej ludność dostawała publikowany w Moskwie „Chołmskij Narodnyj

${ }_{14}$ Від Редакиї, „Рідне Слово”, I 1919, № 74, с. 1.

15 J. Cabaj, op. cit., s. 172. 
Kalendar” ze spisem carów, książąt i patriarchów moskiewskich. „Za drobne fenigi - jak zaznaczano - ofiarowane przez jeńców mogła funkcjonować [gazeta - J.C.]"16. Pismo ukazywało się więc dzięki wsparciu udzielanemu przez Ukraińców pozostających w obozach na terenie Niemiec ${ }^{17}$. Spośród nich rekrutowali się też „,siczownicy” ${ }^{18}$, pozyskani przez ZWU członkowie Hromady wydającej „Ridne Słovo”. Jednak wsparcie ze strony wojskowych ukraińskich skończyło się wraz z wyjazdem większości żołnierzy na Naddnieprze, gdzie włączyli się w obronę tworzącego się państwa ukraińskiego przed agresja bolszewicka. Miało to miejsce na początku 1918 r. W związku z odpływem żołnierzy Hromada zawiesiła działalność. W trudnej sytuacji kadrowej i materialnej znalazła się redakcja „Ridnego Słova”. Nie mając wsparcia przybyszów, musiała odwołać się do miejscowego społeczeństwa. Stąd też w poszukiwaniu protektora dla wydawanego pisma w miejsce Hromady zostało powołane Oświatowo-Wydawnicze Towarzystwo „Ridne Słovo”. Jego regulamin przyjęto w sierpniu 1918 r. Towarzystwo przekształciło się w organizację społeczna, której członkiem mógł być każdy Ukrainiec, akceptujący statut i wnoszący składkę roczną w wysokości 20 marek $^{19}$.

To otwarcie na miejscowe siły zostało zaakcentowane w artykule zamieszczonym na łamach „Ridnego Słova” 7 IX 1918 r. Redakcja zwróciła się z apelem „do wszystkich świadomych obywateli” o współpracę w redagowaniu i materialnym wspieraniu pisma. Szczególnie liczyła na angażowanie się nauczycieli, urzędników i duchowieństwa. Wskazywała przy tym na znaczenie słowa drukowanego na tych „najbardziej na zachód wysuniętych terenach ukrainnych”. „Ridne Słovo” miało wspierać organizację życia narodowego mieszkańców Podlasia i bronić ich „przed naporem sassiadów”. Redakcji chodziło tu o Polaków. Postrzegała ich jako głównych przeciwników w procesie odrodzenia narodowego Ukraińców. Uwzględniając doświadczenia z ponadrocznej działalności, zwróciła się z apelem o wsparcie nauczycieli i nauczycielek, dla których - w jej ocenie - „budzenie świadomości narodowej jest obowiązkiem”, gdyż „wróg nie śpi”. W zakończeniu akcentowano konieczność zachowania linii programowej ZWU, „który wyznaczał pierwsze kamienie milowe na szlaku państwowości ukraińskiej" ${ }^{20}$.

„Vistnyk Chołmskago Gubernijalnogo Starostva” był drugim chronologicznie periodykiem ukraińskim, docierającym do mieszkańców powiatów nadbużańskich, a wydawanym w Brześciu. Z jego pierwszego numeru dowiadujemy się o wcześniejszych działaniach Ukraińców, mających na celu publikowanie

16 Від Редакцї, „Рідне Слово”, I 1919, № 74, с. 1.

17 О. Скоропис-Йолтуховський, ор. cit., с. 220-235.

18 „Siczownicy” - członkowie utworzonego w obozie jenieckim w Rastatt I Zaporoskiego Pułku Siczowego im. Tarasa Szewczenki. J. Cabaj, op. cit., s. 164.

${ }^{19}$ Ibidem, s. 177.

${ }^{20}$ Від Редакиї̈. До громадян Холмщини Підляшша й Полісся, „Рідне Слово”, 7 IX 1918, № 36 , c. 1 . 
i kolportaż pisma urzędowego. Już wiosną 1918 r. w Brześciu został przygotowany „Vistnyk Krajevogo Komysarijatu Ukrajinskoj Narodnoj Respubliki na Chołmščynu, Pidljašje i Polissje”. Pismo miało ukazać się z datą 12 IV 1918 r., ale nie dostało się do obiegu. Drugi numer był również przygotowany do druku, jednak też nie trafił do czytelników. Dotychczas - jak informowała w sierpniu 1918 r. redakcja „Vistnyka ChGS” - nie było możliwości wydawania z przyczyn niezależnych od starostwa. Nie podano jednak, z jakich. Zapewne przyczyn zawirowań w wydawaniu pisma należy upatrywać w sytuacji wewnętrznej Ukrainy - zamachu Skoropadskiego i ustanowieniu hetmanatu. W następstwie placówka w Brześciu przekształciła się - jak wskazano we wstępie - z krajowego komisariatu w starostwo gubernialne ${ }^{21}$.

Wraz z nazewnictwem struktur administracyjnych nastapiła zmiana tytułu pisma urzędowego. Ostatecznie w obiegu pojawił się „Vistnyk ChGS”, mający w podtytule zapis „pismo urzędowe”. Ukazywał się w Brześciu od 31 VIII 1918 r. przy ul. Szosowej 8. Redakcja przewidywała cotygodniową częstotliwość wydawania gazety. Jednak nie udało się tego w pełni zachować. Po pojedynczych pięciu numerach, kolejny, 16 października, ukazał się jako podwójny. Następny - ósmy został wydany z datą 26 października. Kolejne zaś pojawiały się regularnie. Ostatni z tych, do których miałem dostęp, nr 14 ukazał się 7 XII 1918 r. Po tym wydano jeszcze trzy. Wskazuje na to numeracja „Vistnyka KK”, będącego kontynuacja „Vistnyka ChGS”. Problem ten rozwijam w dalszej części pracy.

„Vistnyk ChGS” wydawano w drukarni Chełmskiego Starostwa Gubernialnego w Brześciu. Redaktorem naczelnym był P. Bazylewicz. Nie znamy wielkości nakładu pisma. Zamierzeniem redakcji było docieranie do wszystkich urzędów ukraińskich na terenach wchodzących w skład starostwa. Skutecznemu kolportażowi miała zapewne służyć zapisana pogrubionym drukiem informacja, która pojawiła się w numerze ósmym i była zamieszczana w kolejnych. Przypominano w niej urzędom ukraińskim o obowiązku uiszczenia prenumeraty za pismo. Ze strony tytułowej można dowiedzieć się, iż odpłatność za pojedyncze egzemplarze wynosiła na miejscu w Brześciu 20 fenigów, zaś w sprzedaży wysyłkowej - 25 fenigów ${ }^{22}$.

Kontynuacja „Vistnyka ChGS” był - jak już wspomniano - „Vistnyk KK”. W pierwszym numerze tego ostatniego znajdujemy uzasadnienie zmiany tytułu. Redakcja informowała, że wraz z ponownym ustanowieniem Ukraińskiej Republiki Ludowej zastapiono nazwy stanowisk urzędowych: ze „starostwo” - „starosta” na „komisariat” - „komisarz”. W zwiąku z tym przemianowanie zastosowano $\mathrm{w}$ tytule czasopisma ${ }^{23}$.

${ }^{21}$ Не урядова частина. Від Редакиї, „Вістник Холмського Губерніяльного Староства”, 31 VIII 1918, № 1, c. 4.

22 [Brak tytułu], „Вістник Холмського Губерніяльного Староства”, 26 X 1918, № 8, с. 1.

${ }_{23}$ Від редакцї̈, „Вістник Краєвого Комісаріяту Української Народньої Республікии на Холмщиу, Підляше й Полісся”, 12 I 1919, № 1-2, с. 3. 
W zbiorach Lwowskiej Narodowej Naukowej Biblioteki Ukrainy im. W. Stefanyka zachowały się tylko dwa spośród trzech numerów „Vistnyka KK” wydanych w 1919 r. ${ }^{24}$ Pierwszy, podwójny, ukazał się w Brześciu w niedzielę 12 I 1919 r., z numeracją 18-19, nawiązująca do wcześniejszego „Vistnyka ChGS”. Na drugim z zachowanych egzemplarzy widnieje wtorek, 28 stycznia. Był zapewne ostatni, gdyż - jak podano wyżej - miasto zostało wkrótce zajęte przez polskie oddziały wojskowe.

Jak wynika z zapisów na stronach tytułowych, redakcja „Vistnyka KK” znajdowała się w Brześciu przy ul. Miodowej 39, administracja zaś przy Szosowej 8. Adres podano w wersjach ukraińsko- i niemieckojęzycznej. Na stronie tytułowej podwójnego numeru pisma z 1919 r. została zamieszczona informacja, że „Vistnyk KK” ukazuje się „póki co” raz w tygodniu, a jego prenumerata za pół roku wynosi 9 hrywien. Podobnie jak w „Vistnyku ChGS" pogrubiona czcionka przekazywano polecenie, iż wszystkie ukraińskie instytucje urzędowe w granicach komisariatu powinny wysłać przedpłatę na czasopismo. Redakcja zachęcała nauczycieli i nauczycielki do nabywania pisma za pośrednictwem ukraińskich komisariatów powiatowych, a w przypadku ich braku, najbliższych komendantur niemieckich. Do tych ostatnich „Vistnyk KK” rozsyłano po 1-2 egzemplarze na każdą wieś. $\mathrm{Z}$ odrębnym apelem zwracano się do ukraińskich komisarzy powiatowych, aby dołożyli starań, by pismo docierało do wszystkich szkół i urzędów. Od nauczycieli spodziewano się pomocy w zbieraniu przedpłat na „Vistnyk KK". Sumy te zaś miały trafiać do redakcji za pośrednictwem komisariatów powiatowych ${ }^{25}$.

Za zgodą i przy wsparciu Chełmskiego Starostwa Gubernialnego w Brześciu od 1 X 1918 r. w mieście tym wydawano „Myr” ( мup - pokój). Łącznie do czytelników trafiło dziewięć numerów - ostatni 21 XII 1918 r. Nie znamy powodów nieukazywania się tego pisma w styczniu 1919 r., gdy jeszcze Brześć był we władaniu Niemców i działał tam komisariat ukraiński. Czy na zaprzestanie jego wydawania miały wpływ zmiany polityczne związane z upadkiem Skoropadskiego i reaktywowaniem Ukraińskiej Republiki Ludowej? Na to pytanie nie udało mi się znaleźć odpowiedzi.

Redakcja i administracja „Myra” znajdowały się w siedzibie starostwa ukraińskiego, w którego drukarni pismo było wydawane. „Myr” - jak zapisano w podtytule - miał ukazywać jako tygodnik, w każdy wtorek. Jednak redakcji nie udało się zachować tej regularności. W odstępie tygodniowym ukazały się dwa pierwsze numery. Trzeci wydano 19 października (sobota), następny tydzień później. Piąty numer pojawił się po dwóch tygodniach. Następne zostały wydane z zakładaną pierwotnie częstotliwościa.

${ }^{24}$ I. Павлюк, М. Мартинюк, ор. cit., с. 382-383.

${ }_{25}$ Від редакцї̈, „Вістник Краєвого Комісаріяту Української Народньої Республікии на Холмщиу, Підляше й Полісся”, 12 I 1919, № 1-2, с. 5. 
Redaktorem i zarazem autorem większości artykułów w nim zamieszczonych był - jak już wskazano - Mychajło Kit, duchowny greckokatolicki z Galicji, w ukraińskich opracowaniach encyklopedycznych określany jako rzecznik „umacniania ukraińskiej państwowości, walki o kulturę, ukraiński kościół narodowy, przeciw polskim działaniom”26. I te cele realizował w wydawanym przez siebie piśmie.

Ksiądz Kit ze swoim pismem miał trafiać do grupy ludności, do której trudno było dotrzeć prawosławnym działaczom Hromady w Białej Podlaskiej czy starostwa w Brześciu, pochodzącym w większości z Ukrainy rosyjskiej. Zwracał bowiem uwagę na miejscową społeczność obrządku rzymskokatolickiego, w znacznej części składająca się z potomków dawnych unitów, określanych mianem „kałakutów”27. Odbiorcami pisma ks. Kita mieli być zatem przede wszystkim mieszkańcy nadbużańskiego Podlasia oraz Chełmszczyzny pozostajacej pod okupacją austriacka w granicach generał-gubernatorstwa lubelskiego.

\section{Przekaz informacji i wspieranie działań narodowych}

Opisywane czasopisma prowadziły szeroko rozumianą działalność informacyjna, a także wspierały poczynania organizacji społecznych i struktur państwa ukraińskiego. Nie znajdowały na ich łamach odbicia konflikty polityczne toczące się na Ukrainie. Wynikało to zapewne z jednej strony z dynamiki wydarzeń, z drugiej zaś identyfikowania się wydawców z aktualnie rządzącą opcja.

$\mathrm{Na}$ znaczenie prasy w życiu lokalnej społeczności dobitnie wskazała redakcja „Vistnyka ChGS” w pierwszym numerze, podkreślając, że ludność Chełmszczyzny, Podlasia, Polesia i zachodniej części Wołynia nie ma kontaktów z pozostałymi terenami Ukrainy. Nie otrzymuje żadnych czasopism oprócz wydawanego w Białej „Ridnego Słova”. Dlatego - jak zauważała redakcja - „nie wiedzą miejscowi co dzieje się na świecie, na Ukrainie, a nawet w pobliżu, na ziemiach okupowanych". I tę lukę miało zapełnić wydawane pismo, „dostarczając odbiorcom informacji, przekazując wskazówki i porady, czego tylko potrzebują mieszkańcy tych zrujnowanych terenów"28.

W opisywanych czasopismach zwykle na pierwszej stronie eksponowano aktualności z życia regionu, państwa ukraińskiego i polityki międzynarodowej. Tak np. w „Ridnym Słovie” stałą rubrykę stanowiły wieści z Ukrainy, zatytułowane najpierw „Iz Ukrajini”, później „Po Ukrajini”. W piśmie na

\footnotetext{
${ }^{26}$ Енииклопедія сучасної Украӥни, т. ХХ, Київ 2018, с. 467.

${ }^{27} \mathrm{Na}$ Ukrainie terminem „kałakuta” określa się mieszkańców Podlasia, dawnych unitów, którzy byli poddani przymusowemu nawracaniu na prawosławie, a po 1905 r. przyjęli katolicyzm łaciński i ulegli polonizacji. Енииклопедія сучасної Украӥни..., т. XII, Київ 2012, с. 8.

${ }^{28}$ Не урядова частина..., с. 4.
} 
bieżąco informowano o działalności Ukraińskiej Hromady i ZWU, a po ich rozwiązaniu i wraz z tworzeniem struktur państwowych ukraińskich o aktywności tych ostatnich.

Stały i przejrzysty układ miały pisma starostwa gubernialnego i komisariatu krajowego w Brześciu. I tak od początku ukazywania się „Vistnyka ChGS” były w nim wyodrębnione dwie części: „urzędowa” i „nieurzędowa”. Objętość tej pierwszej stale zmniejszała się na rzecz drugiej - od jednej do niespełna pół strony sześciostronicowego wydania ${ }^{29}$. Na przykład trzeci numer pisma zawierał tylko jedno ogłoszenie kijowskiego Ministerstwa Spraw Wewnętrznych, resztę zaś stanowiła część „nieurzędowa”. W niej m.in. ukazano aktualne relacje ukraińsko-niemieckie ${ }^{30}$. Zamieszczono też obszerną informację o powstaniu w Białej Podlaskiej Oświatowo-Wydawniczego Towarzystwa „Ridne Słovo”. Wyjaśniono w niej powody zaprzestania działań Ukraińskiej Hromady sprawującej patronat nad pismem od początku jego powstania. Redakcja „Vistnyka ChGS” umieściła także reklamę „Ridnego Słova" ${ }^{31}$. W następnych wydaniach znajdował się adres, na który należy składać przedpłaty na bialskie pismo.

W „nieurzędowej” części „Vistnyka ChGS” pojawiały się też informacje o aktywności ukraińskiej administracji krajowej i organizacji szkolnictwa. Wiele miejsca poświęcano działaniom starosty krajowego Ołeksandra Skoropysa-Jołtuchowskiego ${ }^{32}$. W tym samym numerze pisma zamieszczono informację o organizacji kursów ukrainoznawstwa dla nauczycieli szkół z okupowanych przez wojska państw centralnych terenów Chełmszczyzny, Podlasia, Polesia i zachodniego Wołynia ${ }^{33}$.

Od drugiego numeru na łamach „Vistnyka ChGS” pisano o konieczności przestrzegania rozporządzeń władz okupacyjnych. W uzasadnieniu redakcja wskazywała, że „dopóki na ziemiach okupowanych nie będzie wojska ukraińskiego i milicji, które strzegłyby porządku i spokoju w kraju, faktyczna władza spoczywa w rękach niemieckich władz okupacyjnych i ich rozporządzenia muszą być wykonywane na równi z zarządzeniami Chełmskiego Starostwa Gubernialnego, które wydaje je w porozumieniu z [niemiecką - J.C.] Inspekcją Etapową Bug" ${ }^{34}$.

29 [Brak tytułu], „Вістник Холмського Губерніяльного Староства”, 7 XII 1918, № 14, с. 1.

30 Tej tematyce były poświęcone trzy artykuły: Гетьлан у Берліні, Нілеччинна й Украйна, III-я Украӥнська міжтаборова конфберениія в Німеччині, „Вістник Холмського Губерніяльного Староства”, 17 IX 1918, № 3, с. 1-3.

31 Просвітно-Видавниче Т-во „Рідне Слово” в Білій на Підяшшу, „Вістник Холмського Губерніяльного Староства”, 17 IX 1918, № 3, с. 3-4.

32 Поворот n. Краєвого Старосты до Берестя, „Вістник Холмського Губерніяльного Староства", 17 IX 1918, № 3, с. 3.

${ }^{33}$ Курси українознавства в Бересті, „Вістник Холмського Губерніяльного Староства”, 17 IX 1918, № 3, с. 3.

${ }^{34}$ [Brak tytułu], „Вістник Холмського Губерніяльного Староства”, 7 IX 1918, № 2, с. 1. 
„Vistnyk KK” miał podobny układ jak jego poprzednik - „Vistnyk ChGS”, z podziałem na części „urzędowa” i „nieurzędowa”. Pierwsza zawierała aktualne zarządzenia władz centralnych i krajowych, druga zaś sprawy różne. W części „urzędowej” przywoływanego już podwójnego wydania z 12 I 1919 r. znalazła się informacja o wprowadzeniu przez komisarza Ołeksandra Skoropysa-Jołtuchowskiego stanu wyjątkowego na terenie Chełmszczyzny, Podlasia i Polesia. Z zamieszczonej wzmianki wynikało, że ukraiński komisarz krajowy 2 I 1919 r. przeją od Niemców władzę nad krajem. Z tym dniem wprowadził też stan wyjątkowy oraz polecił podległej sobie administracji, milicji oraz oddziałom wojskowym, „aby wobec wszystkich złoczyńców, naruszających spokój społeczny i wobec wrogów Ukraińskiej Republiki Ludowej” stosowali kary i sposoby walki właściwe stanowi wyjątkowemu ${ }^{35}$.

W części „nieurzędowej” pojawiały się teksty podejmujące aktualne problemy regionu. Przykładem jest obszerny artykuł lekarza Wasylego Dmitriuka, pochodzącego z nadbużańskich Kostomłotów, a praktykującego w Brześciu, poświęcony epidemii tyfusu plamistego ${ }^{36}$. Obok tego zostało zamieszczone omówienie sprawy ochrony nad lisem w lasach państwowych. Temat wydawałby się marginalny w warunkach wojny, ale podjęcie go miało wymiar propagandowy. Wskazywało bowiem na aktywność państwa ukraińskiego ${ }^{37}$.

Informację o aktualnych wydarzeniach przekazywał też „Myr”. Pismo to jako jedyne $\mathrm{z}$ opisywanych czasopism zamieszczało przekazy o walkach polsko-ukraińskich w Galicji jesienią 1918 r., a także sytuacji wewnętrznej na ziemiach pozostających pod kontrolą tworzących się wówczas władz polskich. W końcu października pojawił się tekst pod znamiennym tytułem, zapisanym w języku polskim, Polszcza nierzondem stoi. Z zamieszczonej wzmianki wynikało, że na ziemiach polskich wzmogły się napady, zabójstwa, rabunki. Tak przedstawiano wypadki związane z nasilającymi się wystapieniami antyokupacyjnymi. Redakcja informowała o ofiarach wśród żołnierzy i żandarmów niemieckich. Przekaz podsumowała stwierdzeniem, że „niech Polacy robia sobie w domu pokój, a nie czepiają się ukraińskiej Chełmszczyzny i Podlasia. Te ziemie my sami obronimy przed polskimi bandytami”"38.

Wiadomości o sytuacji na ziemiach polskich i walkach polsko-ukraińskich przekazywane przez „Myr” są trudne do zweryfikowania. Można je traktować jako element walki psychologicznej. Dla zwolenników państwa ukraińskiego

${ }_{35}$ Введення виняткого стану (военного положення) на Холмщині, Підляшу й Полісю, „Вістник Краєвого Комісаріяту Української Народньої Республікии на Холмщиу, Підляше й Полісся”, 12 I 1919, № 1-2, с. 1.

36 Л.В. Дмитріюк, Про плямистий тифб, „Вістник Краєвого Комісаріяту Української Народньої Республікии на Холмщиу, Підляше й Полісся”, 12 I 1919, № 1-2, с. 6-7.

37 З місиевого життя. Лісова справа, „Вістник Краєвого Комісаріяту Української Народньої Республікии на Холмщиу, Підляше й Полісся", 12 I 1919, № 1-2, с. 7.

38 Всячина. „Polszcza nierzondem stoi”, „Мир”, 26 X 1918, № 4, с. 4. 
przekazywane informacje miały stanowić wzmocnienie, a wśród Polaków, budujących wówczas zręby niepodległości, budzić poczucie zagrożenia. Tak np. na nastroje miejscowych mogła mieć wpływ informacja o zmierzających w kierunku Chełmszczyzny trzech dywizjach ukraińskich, znajdująca się w numerze z 5 XI $1918 \mathrm{r} .{ }^{39}$ Obok tego pojawił się przekaz o zajęciu przez Ukraińców całej Galicji Wschodniej. We Lwowie - jak podkreślano - „tocza się walki z polskimi szumowinami i bandytami, którzy strzelają z okien". Ponadto w tym samym przekazie zamieszczono pogłoskę o rzekomym zajęciu Chełma przez Ukraińców. W odniesieniu zaś do ziem kontrolowanych przez Polaków pisano, iż „Polacy niezorganizowani, prowadzą walki ze sobą o przejęcie władzy [...] Wojska polskiego nie ma, tylko polscy szowiniści tworzą je naprędce" 40 .

Obok ogólnego przekazu o nieładzie, jaki w opinii „Myru” panował na ziemiach polskich w listopadzie 1918 r., pojawiła się też krótka wzmianka o przejęciu władzy w Warszawie przez Józefa Piłsudskiego ${ }^{41}$.

W kolejnych wydaniach „Myru” znalazły się także doniesienia o polskiej akcji wyzwoleńczej na terenach nadbużańskich ${ }^{42}$, m.in. informacja o rozbrojeniu „niemieckiej wachy” w Nosowie w powiecie bialskim ${ }^{43}$, a także o sytuacji we Włodawie. W relacji z tej ostatniej znalazła się negatywna ocena działań duchowieństwa katolickiego ${ }^{44}$. Krytyka odnosiła się do angażowania się księży w polską akcję wyzwoleńczą.

Redakcje wszystkich opisywanych pism wspierały działalność narodowa prowadzoną przez organizacje i instytucje je wydające. „Ridne Słovo” już w pierwszym numerze zapewniało, iż w piśmie będą zamieszczane „artykuły na tematy ogólne, poezja, opowiadania, szkice, nowele, artykuły o historii naszego kraju, o państwie, doniesienia ludowe, miejscowe przekazy, pieśni itd.” ${ }^{45}$ Miały one służyć „obudzeniu narodu [ukraińskiego - J.C.] z wiekowego snu, podźwignięciu go z bagna, w które wdeptali go obcy - Moskale i Polacy". Redakcja zapewniała, że będzie „strzec interesów ukraińskich w tym zakątku ziem ukraińskich [Chełmszczyzna i Podlasie - J.C.]" ${ }^{46}$.

„Ridne Słovo” od początku swojego istnienia włączało się na szczeblu regionalnym w budowę państwa ukraińskiego. W tej kwestii odwoływano się do postulatów wysuwanych podczas obrad kongresu ukraińskiego, który odbył

${ }^{99}$ Всячина. Добрі вістки, „Мир”, 16 XI 1918, № 5, с. 4.

${ }^{40}$ Всячина. Украӥнці в Галичині, „Мир”, 16 XI 1918, № 5, с. 4.

${ }^{41}$ Всячина. У Польщі, „Мир”, 30 XI 1918, № 7, с. 4.

${ }^{42}$ Szerzej o akcji wyzwoleńczej w powiatach nadbużańskich w listopadzie-grudniu $1918 \mathrm{r}$. zob. P. Łossowski, Zerwane pęta. Usunięcie okupantów z ziem polskich $w$ listopadzie 1918 roku, Warszawa 1986, s. 222-232.

${ }^{43}$ Всячина. В Носові пов. Біла, „Мир”, 8 XII 1918, № 8, с. 4.

${ }_{44}$ Всячина. В повіті Володава, „Мир”, 21 XII 1918, № 9, с. 4.

45 Передплачуйте „Рідне Слово”, „Рідне Слово”, 23 VI 1917, № 1, с. 4.

${ }^{46}$ [Brak tytułu], „Рідне Слово”, 23 VI 1917, № 1, с. 1. 
się w Kijowie w kwietniu 1917 r. ${ }^{47}$ Za istotną uznano sprawę przyszłych granic Ukrainy. Jej obszar - jak zgodnie z ustaleniami kijowskimi informowało „Ridne Słovo” - miał być równy Niemcom, zamieszkały przez 50 mln osób. Taki przekaz o wielkości przyszłego państwa musiał z pewnością oddziaływać na wyobraźnię czytelników. Do tego jeszcze redakcja akcentowała, że Chełmszczyzna i Podlasie stanowią integralną część Ukrainy. Mieszkańcy tych ziem sa „z dawna Ukraińcami, większość z nich do niedawna była unitami, a obecnie po czesści katolikami i prawosławnymi”. Zauważano przy tym, że tereny te zamieszkują też Żydzi i Polacy, ale - już nie do końca zgodnie z prawda - „stanowią mniejszość, skupiona przede wszystkim w miastach i miasteczkach" ${ }^{48}$.

Od początku swojej działalności redakcja „Ridnego Słova” dążyła do kształtowania wśród miejscowej ludności poczucia przynależności do ukraińskiej wspólnoty. Już w drugim numerze pisma, z 30 VI 1917 r., na stronie tytułowej ukazał się artykuł pod znamiennym tytułem Kim jesteśmy?. Jego autor wskazał na zawłaszczenie przez Rosję „tradycji starej Rusi, pozbawiając jej zarazem Ukraińców”, w konsekwencji prowadzące do wynarodowienia tych ostatnich - „zmoskwicenia”. Dostrzegał już tego konsekwencje w postaci akceptowanych przez miejscowych określeń „Małorusin”, „chachoł”. Wskazał na konieczność eliminowania tych terminów, upowszechniania zaś nazw „Ukrainiec” i „Ukraina”. Artykuł kończył się wezwaniem: „jesteśmy wielkim czterdziestomilionowym narodem europejskim, jesteśmy potomkami sławnych ukraińskich kozaków zaporoskich. Jesteśmy Ukraińcami, a nasz kraj to Ukraina" 49 .

Redakcja „Ridnego Słova” zwracała uwagę na rozwój oświaty ukraińskiej. Wyrazem tego były okresowe omówienia tej problematyki. Pierwsze z nich pojawiło się w gazecie już w październiku 1917 r. Jego autor z satysfakcją pisał o powołaniu i rozwoju placówek szkolnych na terenach nadbużańskich okupowanych przez wojska niemieckie. Stwierdził, iż ważnym impulsem były powstanie i działalność Hromady. Wskazał też na zasługi podległej tej ostatniej Ukraińskiej Rady Szkolnej, mającej swoją siedzibę w Białej Podlaskiej. We wrześniu 1917 r. podlegało jej na terenie Podlasia, Polesia i Wołynia 80 szkół z 96 nauczycielami. Placówki te - jak informował autor artykułu - korzystały ze wsparcia „Związku Wyzwolenia Ukrainy, społeczeństwa ukraińskiego oraz jeńców pozostających na terenie Niemiec i Austro-Węgier"50.

${ }^{47}$ Zapewne jest tu odwołanie do zjazdu uchodźców z Chełmszczyzny. Podczas kongresu zorganizowanego w Kijowie 17 IV 1917 r. przyjęli oni rezolucję, w której wyrazili swój protest przeciw włączaniu ich ojczystych ziem w skład mającej odrodzić się Polski. Szerzej zob. Є. Пастернак, ор. cit., с. 150-151.

48 Межі укаӥнської держави, „Рідне Слово”, 23 VI 1917, № 1, с. 1.

${ }_{49}$ Хтол ми?, „Рідне Слово”, 30 VI 1917, № 2, с. 1.

50 Украӥнське шкільництво на занятих украінських зеллях, „Рідне Слово”, 13 X 1917 , № 17 , c. 1 . 
Wymowny w swoim przekazie był tekst zatytułowany Dajcie nam szkołe ukraińska!, zamieszczony na łamach „Ridnego Słova” we wrześniu 1918 r. ${ }^{51}$ Autor, zapewne Andrij Sawczuk, podpisany samym nazwiskiem, został oddelegowany z Chełmskiego Starostwa Gubernialnego w Brześciu do pracy w redakcji „Ridnego Słova” w Białej Podlaskiej ${ }^{52}$. Jak wskazuje tytuł tekstu, zostało w nim wyrażone zapotrzebowanie miejscowej ludności na szkołę ukraińska. Autor przypomniał zasługi członków Hromady, którzy rozpoczęli zakładanie placówek oświatowych, ale musieli wyjechać z Podlasia na Ukrainę, by „bronić ojczyznę przed bolszewikami”. Wyraził jednak przekonanie, że poczynania zainicjowane przez ośrodek bialski przyniosły już rezultaty wśród miejscowej ludności, gdyż z wielu stron - jak podkreślił - napływały apele: „dajcie nam ukraińska szkołę”. Jako delegat władz gubernialnych zadeklarował, że Krajowy Komisariat Oświaty dołoży starań, aby jak najszybciej do kraju powrócili wysiedleni nauczyciele i żeby „podali pomocna dłoń ukraińskiej ludności wiejskiej”53.

W końcu września 1918 r. Sawczuk zamieścił w „Ridnym Słovie” obszerny artykuł podsumowujaccy rok pracy oświatowej na okupowanych przez Niemcy terenach Podlasia, Polesia i Wołynia. Omówił w nim etapy organizacji i liczebność placówek oświatowych. Wskazał na aktualne problemy szkolnictwa ukraińskiego, przede wszystkim dotyczące zapewnienia kadr nauczycielskich i prowadzenia kursów doskonalenia zawodowego. Wyraził też zadowolenie z faktu funkcjonowania blisko 150 szkół ${ }^{54}$.

Ważnym aspektem działalności redakcji „Ridnego Słova” było tworzenie więzi ludności Podlasia ze społecznością ukraińską Galicji i ziem dawnego Imperium Rosyjskiego, okupowanych przez wojska niemieckie. Uwagę zwraca obecność na łamach pisma reklam towarzystw i wydawnictw lwowskich. Przykładem sa wykazy publikacji do nabycia poprzez Krajowe Towarzystwo Gospodarcze „Silskyj Hospodar” we Lwowie ${ }^{55}$. Ponadto księgarnia Ukraińskiej Hromady w Białej Podlaskiej za pośrednictwem tygodnika oferowała czytelnikom zakup literatury ukraińskiej, w tym dzieła Tarasa Szewczenki, Iwana Franki, Mychajły Hruszewskiego i in. ${ }^{56}$

Redakcja „Ridnego Słova” starała się przybliżać swoim czytelnikom życiorysy i dokonania ukraińskich twórców literatury i nauki. Okazją do prezentacji dokonań Hruszewskiego, w tamtym czasie przewodniczącego Centralnej Rady Ukraińskiej, stały się jego 51. urodziny. Autor okolicznościowego biogramu wyeksponował zwiazek uczonego z Chełmem, miejscem

\footnotetext{
51 Дайте нам украӥнську школу!, „Рідне Слово”, 7 IX 1918, № 36, с. 2.

${ }_{52}$ R. Dydycz, op. cit., s. 42.

${ }_{53}$ Дайте нал украӥнську школу!..., с. 2.

${ }_{54}$ Рік просвітної праці, „Рідне Слово”, 28 IX 1918, № 39, с. 1-2.

55 Видавниитво Сїльського Господаря, „Рідне Слово”, 18 VIII 1917, № 9, с. 4.

56 В Книгарнї Украӥнськой Громади в Білій можна дістати такі украӥнські книжки, „Рідне Слово”, 18 VIII 1917, № 9, с. 4.
} 
urodzenia historyka, dokonania naukowe i jego aktualną rolę „przywódcy w walce o wolność Ukrainy" ${ }^{57}$. Podobnie przypadajaca rocznica urodzin stała się okazją do przybliżenia postaci Szewczenki. Poświęcono mu znaczną część wydania z 16 III 1918 r. Zostały w nim zamieszczone obszerny życiorys pisarza, autorstwa naczelnego - Mykoły Sołowiejczuka ${ }^{58}$, a także fragmenty Kobzara i wspomnienia uczestników działalności ukraińskiej w czasach panowania rosyjskiego. Te ostatnie napisał mieszkaniec Kostomłotów - Andrij Sawczuk $^{59}$.

Działania na rzecz budowania struktur państwowych ukraińskich i włączania w nie miejscowej ludności prowadził ks. Kit na łamach „Myru”. Jego akcja była skierowana przede wszystkim do wspomnianych już „kałakutów”, jak też nielicznej po ewakuacji w 1915 r. ludności prawosławnej. Wstęp do podjęcia sprawy tej pierwszej społeczności stanowił artykuł przybliżajaccy wyznanie katolickie, zarówno obrządku wschodniego, jak i łacińskiego. Wskazywano $\mathrm{w}$ tym tekście na rodzimy charakter obydwu ${ }^{60}$. W kolejnym artykule, który ukazał się w numerze 3, znalazło się już konkretne wezwanie: „Ukraińcy r. [rzymscy - J.C.] - katolicy organizujmy się!"61. Podobny charakter miał następny, obszerny artykuł, skierowany do „ukraińskich chłopów i mieszczan obrządku rzymskokatolickiego" "62. Cią dalszy tego tekstu znalazł się na łamach pisma w czterech późniejszych numerach ${ }^{63}$.

Warto bliżej przyjrzeć się artykułowi dotyczącemu Ukraińców obrządku rzymskokatolickiego, zamieszczonemu na stronie tytułowej trzeciego numeru „Myra”. Utrzymany był - jak wyżej wskazano - w formie apelu skierowanego do tej grupy wyznaniowej. Autor tekstu, zapewne ks. Kit, stwierdził na wstępie, utożsamiając się z tą wspólnota przez używanie zaimka „my”, że Ukraińcy łacinnicy stanowią najbardziej upośledzona grupę społeczeństwa. Podlegaja oddziaływaniu „polskich agitatorów”, „polskich księży”, „,jezuitów”, „polskich urzędników". Ich działania powodowały, że łacinnicy zostali wyalienowani z reszty społeczeństwa ukraińskiego. Konsekwencja tego było postrzeganie jako wrogów swoich braci innego wyznania niż rzymskokatolickie. W analizowanym artykule padły oskarżenia pod adresem polskich księży, że za czasów „nieboszczki Polski” i carskich odcinali swoich parafian od rodzimej mowy ukraińskiej. Autor zaapelował do Ukraińców - łacinników, aby nie dawali się dłużej wykorzystywać Polakom, by „nie być janczarami, którzy

\footnotetext{
${ }^{57}$ I. Невеселий, Михайло Грушевський (З нагоди 51.рок.його уродин), „Рідне Слово”, 29 IX 1917, № 15, с. 1.

58 М. Соловейчук, Тарас Шевченко, „Рідне Слово”, 16 III 1918, № 11, с. 1-2.

59 А. Савчук, „Кобзар” на селї, „Рідне Слово”, 16 III 1918, № 11, с. 2-3.

60 Україниі римо-католики на Підляшші, „Мир”, 8 X 1918, № 2, с. 1-2.

61 Українці р.-католики організуйлося!, „Мир”, 19 Х 1918, № 3, с. 1-2.

62 До селян та міщан Українців р. католиков, „Мир”, 16 XI 1918, № 5, с. 1-2.

63 До селян та мішан Украйнців р. католиков (Дальше), „Мир”, 23 XI 1918, № 6, с. 1-2; „Мир”, 30 XI 1918, № 7, с. 1-2; „Мир”, 7 XII 1918, № 8, с. 2; „Мир”, 21 XII 1918, № 9, с. 2.
} 
wychodzą z własnego narodu i później z nim walczą". Wierzył też w możliwość współpracy łacinników i grekokatolików ${ }^{64}$.

Redaktor „Myru”, jak wynika z przekazów pisma, podejmował próby ponownego zaszczepienia na Podlasiu obrządku unickiego. Świadczy o tym uroczystość religijna ku czci św. Mikity, która odbyła się 28 IX 1918 r. w Kostomłotach, rodzinnej miejscowości Karpa Dmitruka, gubernialnego komisarza oświaty, i jego brata Wasylego, lekarza społecznika, praktykującego w Brześciu. Do tej nadbużańskiej wsi, obok obu braci Dmitruków, przybyło również 20 uczestników kursów ukrainoznawczych organizowanych w tym czasie w Brześciu. Pojawił się też ks. Kit, który odprawił nabożeństwo unickie w miejscowej cerkwi prawosławnej. Liturgia - jak wynikało z relacji pisma - była wielkim przeżyciem dla uczestników. Starsi, wśród nich Roman Dmitruk - ojciec wymienionych wyżej, mieli możliwość przypomnieć sobie dawno niesłyszane modlitwy i pieśni unickie. Uroczystość zakończył śpiew ukraińskich pieśni religijnych i patriotycznych ${ }^{65}$.

Podobnych wydarzeń nie odnotowano więcej na łamach „Myru”. Z innych natomiast źródeł dowiadujemy się, że ks. Kit podejmował próbę przejęcia parafii Drelów, w której w 1874 r. doszło do masakry ludności unickiej w okresie brutalnego jej nawracania na prawosławie. Jednak miejscowi, od 1905 r. w większości katolicy obrządku łacińskiego, z nieukrywaną wrogością odnieśli się do duchownego greckokatolickiego. Został on zmuszony do opuszczenia parafii przez mieszkańców wsi wchodzących w jej skład ${ }^{66}$.

Ksiądz Kit posługując się swoim pismem, podobnie jak redakcje czasopism wyżej przedstawionych, dążył do kształtowania poczucia odrębności narodowej miejscowej ludności ukraińskiej. Jako przeciwników na tej drodze widział Polaków. Od pierwszego numeru pisma zainicjował w nim prezentowanie „wrogiej Ukraińcom działalności Polaków” na Chełmszczyźnie i Podlasiu, pod wymownym tytułem Chrześcijańskie (?) uczynki Polaków. Pierwszy odcinek dotyczył sprawy: „Jak Polacy gnębią Ukraińców na Chełmszczyźnie” i był poświęcony ukazaniu tych wschodnich terenów dawnego Królestwa Polskiego, znajdujacych się pod okupacja austriacka, gdzie zdaniem autora cyklu „Polacy chcą nas [Ukraińców - J.C.] uszczesśliwié”67. Miał tu na uwadze działania polskich księży katolickich. Dlatego zachęcał czytelników do informowania o przypadkach „podawania treści antyukraińskich podczas kazań [w kościołach - J.C.], niszczenia cerkwi, zaboru mienia i gnębienia ludności ukraińskiej przez Polaków"68.

\footnotetext{
${ }_{64}$ Україниі р.-католики організуйлося!, „Мир”, 19 Х 1918, № 3, с. 1.

${ }_{65}$ Празник в с. Костоллоти пов. Біла, „Мир”, 8 X 1918, № 2, с. 3-4.

${ }^{66}$ J. Cabaj, op. cit., s. 179.

${ }^{67}$ Християнські (?) вчинки поляків 1. Як поляки гноблять Украӥнців на Холмщині, „Мир”, 8 X 1918, № 2, с. 2-4.

68 Ibidem, s. 2.
} 
Redakcja „Myru” przekazywała na łamach pisma informacje o przejmowaniu przez katolików opuszczonych cerkwi prawosławnych, dawnych unickich, m.in. w Radecznicy w powiecie zamojskim. Działania te, które w relacji gazety miały odbywać się wbrew woli mieszkańców, ukazywano jako przejaw „barbarzyństwa” Polaków. Ci ostatni mieli wyrzucać i niszczyć wyposażenie świątyń. Tę działalność rewindykacyjną według przekazu pisma ukraińskiego prowadzili „ludzie przybyli z Krakowa”. Autor relacji oskarżał ich o sianie nienawiści do Ukraińców i wyznawców prawosławia. Podkreślał, że miejscowa ludność „znowu religijnie i politycznie jest gnębiona przez polskich jezuitów" ${ }^{\prime 2}$.

Podniesiony przez „Myr” problem przejmowania przez katolików świątyń prawosławnych miał zapewne związek z akcja rewindykacji, podjęta przez Antoniego Plutyńskiego. Intencją pomysłodawcy, związanego z Departamentem Wojskowym Naczelnego Komitetu Narodowego i lubelska „Gazetą Ludową, było przywrócenie obiektów sakralnych pierwotnym właścicielom - Kościołowi katolickiemu, któremu obiekty te zostały odebrane w okresie prześladowań unitów i przekazane wyznawcom prawosławia. Akcja miała na celu pozyskanie sympatii miejscowej ludności dla poczynań biur werbunkowych. Na przykład wydarzeniem o zasięgu ponadlokalnym było przekazanie katolikom wspomnianych przez redakcje „Myru” obiektów klasztornych w Radecznicy. W uroczystościach, które miały miejsce 13 VI 1916 r., wzięło udział 15 tys. chłopów z powiatów krasnostawskiego i zamojskiego ${ }^{70}$.

Na łamach „Myru” znalazło się jeszcze 12 odcinków cyklu pt. Chrześcijańskie (?) uczynki Polaków.

Lata 1917-1919 były pierwszym okresem zorganizowanej ukraińskiej działalności narodowej na nadbużańskich terenach Podlasia, Chełmszczyzny, Polesia i Wołynia. Najpierw powstała w Białej Podlaskiej legalna Ukraińska Hromada, a od wiosny 1918 r. struktury administracyjne tworzącego się państwa ukraińskiego. Ważną rolę w ich poczynaniach odegrała prasa, która wydawana w Białej Podlaskiej i Brześciu trafiała do odbiorców na wymienionych wyżej terenach. Pełniła przede wszystkim funkcję informacyjna, dostarczając czytelnikom wiedzy dotyczącej życia społeczno-politycznego, kulturalnego i gospodarczego w skali regionalnej, jak i w odniesieniu do całej Ukrainy. Starała się tym samym włączać miejscowe społeczeństwo w sprawy narodowe i państwowe. Czasopisma przedstawione w artykule wpływały na kształtowanie poczucia odrębności narodowej ludności ukraińskiej, upowszechniały wśród niej idee niepodległej Ukrainy z powiatami nadbużańskimi w jej granicach.

Oryginalny i wymagający pogłębionych badań jest projekt pozyskania dla państwa ukraińskiego społeczności rzymskokatolickiej określanej „kałakutami”,

69 Ibidem, s. 3.

${ }^{70}$ J. Cabaj, op. cit., s. 147. 
zamieszkującej powiaty nadbużańskie, a także przywrócenia tam obrządku greckokatolickiego. Działania te podjął ks. Mychajło Kit, a realizował przez wydawanie czasopisma „Myr”.

\section{Streszczenie}

Artykuł jest poświęcony prasie ukraińskiej ukazującej się w latach I wojny światowej na terenie nadbużańskiego Podlasia (Biała Podlaska) lub poza nim (Brześć), ale adresowanej i docierającej do miejscowej ludności. Czasopisma mogły ukazywać się dzięki aprobacie niemieckich władz okupacyjnych. Wydawaniem ich zajmowały się organizacje społeczne, religijne i terenowe komórki administracji ukraińskiej. Pisma odgrywały istotną rolę propagandowa, szczególnie w zakresie organizacji działań na rzecz odrodzenia życia narodowego miejscowej ludności oraz upowszechniania idei budowy niepodległego państwa ukraińskiego z powiatami nadbużańskimi w jego granicach. Redakcje zaprzestały swojej działalności wraz z ustapieniem niemieckich władz okupacyjnych i włączeniem terenów nadbużańskich w skład odradzającej się Polski.

\section{Ukrainian Press in Podlasie in 1917-19}

The article presents the characteristics of the Ukrainian press published during World War I in the territory of Podlasie or outside it (Brest) but addressed and reaching the local population. These papers could be issued owing to the approval of the German occupation authorities. They were published by social, religious, and local units of Ukrainian administration. They played a vital propagandistic role, especially in the organisation of activities to revive the national life of local people and to propagate the idea of reconstructing an independent Ukrainian state with the Bug River districts within its borders. The editorial staffs stopped issuing their papers with the withdrawal of the German occupation authorities and the incorporation of the Bug River areas into the territory of reborn Poland.

\section{Bibliografia}

Cabaj J., Społeczeństwo guberni chetmskiej pod okupacja niemieckq $i$ austriacka $w$ latach I wojny światowej, Siedlce 2006.

Dydycz R., Od narodzin do likwidacji. Ukrainska działalność polityczna, społeczna, kulturalno-oświatowa $i$ gospodarcza na terenie powiatu bialskiego w latach 1917-1947, mps rozprawy doktorskiej, Siedlce 2019.

Grobicki J., Zajęcie Brześcia Litewskiego w lutym 1919 r. i poprzedzajace je wypadki na Podlasiu, „Bellona” 1932, t. XXXIX.

Łossowski P., Zerwane pęta. Usunięcie okupantów z ziem polskich w listopadzie 1918 roku, Warszawa 1986.

Misiło E., Spis tytułów prasy ukraińskiej w Drugiej Rzeczypospolitej 1918-1939, Warszawa 1983.

Горний М., Українська інтелігениія Холмщини і Підляшшя у ХХ ст., Львів 2002.

Енииклопедія сучасної України, т. XII-XX, Київ 2012-2018.

Купріянович Г., Украӥнський етнос на Холмщини та Підляшші у XIX-XX ст., в: Холмщина та Підляшщя. Історико-етнограббічне дослідження, ред. В. Борисенко, Київ 1997, c. 59-76. 
Макар Ю., Холмщина і Підляшшя в першій половині ХХ століття. Історико-політична проблелтика, Львів 2003.

Павлюк І., Мартинюк М., Хрестоматія украӥнськой преси Волині Полісся Холщини та Підляшшя 1917-1939, 1941-1944 рр., Луцьк 2005.

Пастернак Є., Нарис історї Холмщини і Підляшщя (новіші часи), Вінніпег-Торонто 1968. Патер І., Союз визволення України. Проблели державності і соборності, Львів 2000.

Супронюк О., Часопис "Вісник Союзу Визволення Украйни» (Відень, 1914-1918) як чинник становлення державності України, „Наукові записки Національного університету «Острозька академія». Серія «Історичні науки»" 2015, Вип. 23.

Jarosław Cabaj - dr hab., profesor w Instytucie Historii Uniwersytetu Przyrodniczo-Humanistycznego w Siedlcach. Prowadzi badania nad prasą regionalną XIX-XX w. Podejmuje też problematykę więzi polskich środowisk naukowych i społeczno-zawodowych w okresie zaborów. E-m ail: jaroslaw.cabaj@uph.edu.pl.

Jarosław Cabaj - Dr hab., professor at the Institute of History of Siedlce University of Natural Sciences and Humanities. He conducts research on the regional press of the $19^{\text {th }}$ and $20^{\text {th }}$ centuries, also deals with the issues of relationships between Polish scientific and socio-professional communities during the partitions. E-mail: jaroslaw.cabaj @uph.edu.pl. 